Article

\title{
Influence of Flow and Pressure of Carburising Mixture on Low-Pressure Carburising Process Efficiency
}

\author{
Emilia Wołowiec-Korecka $^{1, * \mathbb{D}}$, Maciej Korecki ${ }^{2}$ and Leszek Klimek ${ }^{1}$ D \\ 1 Institute of Materials Science and Engineering, Faculty of Mechanical Engineering, Lodz University of \\ Technology, B. Stefanowskiego 1/15, 90-924 Lodz, Poland; leszek.klimek@p.lodz.pl \\ 2 Seco/Warwick S.A., J. Sobieskiego 8, 66-200 Swiebodzin, Poland; maciej.korecki@secowarwick.com \\ * Correspondence: emilia.wolowiec-korecka@p.lodz.pl
}

check for updates

Citation: Wołowiec-Korecka, E.; Korecki, M.; Klimek, L. Influence of Flow and Pressure of Carburising Mixture on Low-Pressure Carburising Process Efficiency. Coatings 2022, 12, 337. https:// doi.org/10.3390/coatings12030337

Academic Editors: Fernando Pedraza and Georgios Skordaris

Received: 27 December 2021

Accepted: 3 March 2022

Published: 4 March 2022

Publisher's Note: MDPI stays neutral with regard to jurisdictional claims in published maps and institutional affiliations.

Copyright: (C) 2022 by the authors. Licensee MDPI, Basel, Switzerland This article is an open access article distributed under the terms and conditions of the Creative Commons Attribution (CC BY) license (https:// creativecommons.org/licenses/by/ $4.0 /)$.

\begin{abstract}
Low-pressure carburising (LPC) of steel is an industrially accepted method for improving the properties of a steel surface. LPC is environmentally friendly, does not cause intergranular oxidation and consumes less energy. Its effectiveness depends on the correct choice of process inputs. This paper aims to determine the effect of this type of carboniferous gas, pressure and flow rate on the efficiency of carbon transfer to the surface layer under low-pressure carburisation. A total of 40 disks of $16 \mathrm{MnCr} 5$ steel were carburised using pure acetylene or a mixture of acetylene, ethylene and hydrogen as a carboniferous gas, pressures of 2 or $6 \mathrm{hPa}$ and two gas flow rates. The specimens were gravimetrically tested for the increase in the mass of carbon in the carburised layer. The results were analysed with U Mann-Whitney analysis and t-Student test. It was evidenced that carburising with pure acetylene resulted in a higher increase in carbon mass than carburising with the mixture $(p<0.05)$. Pressure and gas flow rates are important for carburising efficiency $(p<0.05)$.
\end{abstract}

Keywords: low-pressure carburizing; carburizing mixture; process efficiency

\section{Introduction}

Low-pressure carburising (LPC) is a modern method of steel surface strengthening. The higher temperature of vacuum carburising (as compared to gas carburising) results in higher carbon transfer than in the traditional carburising method and the process time is shorter. Furthermore, LPC is environmentally friendly; it does not cause intergranular oxidation and consumes less energy [1]. After quenching, carburised steel is often harder than raw steel. In this version, it can be used for any industrial applications where wear resistance under operating conditions is important [1-4].

\section{Low-Pressure Carburizing}

The low-pressure carburising process is organised in cyclically repeated boost and diffusion stages where, in the boost stage, the intense surface and diffusion processes occur in the treated piece and, in the diffusion stage, only diffusion processes take place, without carbon being supplied to the surface. In a vacuum furnace chamber, a reduced pressure $(1-10 \mathrm{hPa})$ is created and then, at a temperature of $900-1050{ }^{\circ} \mathrm{C}$, small amounts of hydrocarbons (Table 1)—which are the source of carbon-are cyclically supplied. The raw steel is heated in this environment for the time required to obtain the desired distribution of carbon concentrations in the surface layer [5,6].

Carburising is a process involving three basic phenomena: (1) the transfer of carbon atoms from the atmosphere to the steel surface; (2) chemical reactions (adsorption and absorption) on the surface; and (3) diffusion of absorbed carbon atoms into the material in accordance with the direction of the concentration gradient $[7,8]$. The total rate of carbon transfer from the atmosphere to the steel is, therefore, determined by the limiting process, which kinetically becomes the stage controlling the carburisation rate. From this point of 
view, it is essential to supply carboniferous gas to the steel surface in an amount adequate to the carbon demand, otherwise it could become a process decelerating factor $[9,10]$. Too little an amount of carboniferous gas in the carburising chamber results in obtaining an uneven carburised layer and, consequently, a batch of elements would already be rejected from use at the production stage. Too large an amount of gas causes carbon derivative substances (soot and tar) to deposit in the furnace chamber, which means taking the equipment out of service for cleaning [11-14]. The amount of active carbon atoms in the chamber is determined by the type of carboniferous gas, the manner of its decomposition and its pressure and flow rate.

Table 1. Carboniferous gases and mixtures used in low-pressure carburising (LPC) [10,15].

\begin{tabular}{|c|c|}
\hline Family & Combinations \\
\hline \multirow{5}{*}{ Acetylene and Aceylene mixtures } & $100 \%$ Acetylene $\left(\mathrm{C}_{2} \mathrm{H}_{2}\right)[16]$ \\
\hline & Acetylene + Nitrogen ${ }^{a}$ \\
\hline & Acetylene + Hydrogen ${ }^{b}[17]$ \\
\hline & Acetylene + Etylene $\left(\mathrm{C}_{2} \mathrm{H}_{4}\right)+$ Hydrogen $^{c}$ [5] \\
\hline & Acetylene + Cyclohexane \\
\hline \multirow{2}{*}{ Cyclohexane and Cyclohexane Mixtures } & $100 \%$ Cycloxehane $\left(\mathrm{C}_{6} \mathrm{H}_{12}\right)[6]$ \\
\hline & Cycloxehane + Acetylene \\
\hline \multirow{2}{*}{ Methane and Methane Mixtures } & $100 \%$ Methane $\left(\mathrm{CH}_{4}\right)$ \\
\hline & Methane + Propane \\
\hline \multirow{4}{*}{ Propane and Propane Mixtures } & $100 \%$ Propane $\left(\mathrm{C}_{3} \mathrm{H}_{8}\right)$ \\
\hline & Propane + Methane $\mathrm{d}$ \\
\hline & Propane + Hydrogen \\
\hline & Propane + Butane $\left(\mathrm{C}_{4} \mathrm{H}_{10}\right)$ \\
\hline
\end{tabular}

a Typical dilutions up to $50 \%{ }^{\mathrm{b}}$ Typical dilution $7: 1 .^{\mathrm{c}}$ Typical ratios of acetylene to ethylene to hydrogen are 3:2:1 or 2:2:1. ${ }^{\mathrm{d}}$ Typical dilution: $40 / 60$ to $60 / 40$ (methane/propane).

The decomposition process of carboniferous gases (light hydrocarbons) at high temperature(s) is well-studied [11-13,18-24]. The dosage of gas quantity is optimised based on empirical formulas such as the Harris equation $(1944)[9,25]$ or numerical formulas [26]. However, since the pressure and gas flow rate in the chamber are closely related, their exact influence on process efficiency has not been clearly explained. An additional factor that makes the determination of the proper amount of carboniferous gas difficult is that not all gas introduced into the carburising chamber dissociates completely. The degree of dissociation depends on temperature and on changes over time, and its value can be determined only experimentally [9]. For traditional atmospheric carburisation, it is assumed that the batch absorbs no more than a few percent of the carbon available from the carburising atmosphere. Therefore, when calculating the flow rate, to ensure a homogeneous layer, gas is supplied with an excess of several dozens of times. In low-pressure carburising the dosed size of carburising mixture is three to four times bigger than the calculated surface absorption capacity. The method of calculating the flow rate of carburising gas for acetylene was proposed by Antes, who noted that the procedure requires knowing the curve of a fraction of acetylene dissociated in temperature and time function, determined experimentally [9]. This is an important scientific problem and continues to be a gap in the literature that needs to be filled.

This paper aims to determine the effect of the type of carboniferous gas, pressure and flow rate on the efficiency of carbon transfer to the surface layer under low-pressure carburisation, which is a step towards filling the knowledge gap described above. The three following null hypotheses were tested: (1) no differences in carbon transfer effectiveness would be found between specimens that were in $100 \% \mathrm{C}_{2} \mathrm{H}_{2}$ gas carburised and those that were in $\mathrm{C}_{2} \mathrm{H}_{2}, \mathrm{C}_{2} \mathrm{H}_{4}$ and $\mathrm{H}_{2}$ mixture carburised; (2) pressure would not affect carbon transfer into steel; and (3) gas flow would not affect carbon transfer into steel. 


\section{Materials and Methods}

The experiment was designed according to a bivariate (two-level) plan used to model linear dependencies with possible two-factor interactions. Forty disc-shaped specimens of $16 \mathrm{MnCr} 5$ steel were washed and weighed on a laboratory scale with a $0.001 \mathrm{~g}$ measurement accuracy. The discs were then carburised in a vacuum furnace (VPT 20/24, SecoWarwick, Swiebodzin, Poland) at $960^{\circ} \mathrm{C}$ in one of two carboniferous mediums presented in Table $1-$ pure acetylene or a mixture of acetylene, ethylene and hydrogen in a 2:2:1 ratio. The same process segmentation was used for all processes in which the carboniferous gas boost stages lasted for $10 \mathrm{~min}$ in total, and the diffusion stages lasted for $60 \mathrm{~min}$ in total. The process variables included the type of carboniferous gas (acetylene, mixture of acetylene and ethylene), pressure (1-7 hPa) and flow $\left(6-11.25 \mathrm{dm}^{3} / \mathrm{min}\right)$. The types of carboniferous gas were selected based on data used in practice $[16,27]$. The range of pressures and their fluctuations were selected based on publications on low-pressure carburisation $[5,27,28]$. The range of flows was matched to the size of the estimated absorptivity of $16 \mathrm{MnCr} 5$ steel at $960{ }^{\circ} \mathrm{C}$. Immediately after the carburising phase, the specimens were cooled rapidly to stop the carbon absorption process. After the thermo-chemical treatment, the specimens were washed and weighed again (gravimetric method). The results were then analysed in terms of the research hypotheses for each series of processes $\left(\mathrm{C}_{2} \mathrm{H}_{2}\right.$ and $\left.\mathrm{C}_{2} \mathrm{H}_{2}: \mathrm{C}_{2} \mathrm{H}_{4}: \mathrm{H}_{2}\right)$.

\section{Results}

The results of the measurements of carbon transferred into the surface layer of the specimens are shown in Tables 2 and 3. By analysing the results in terms of the effect of the type of carboniferous medium, a higher mass increase was observed in processes where pure acetylene was used. The differences in the average increase in mass of carbon between the groups carburised with acetylene and the mixture were significant (Mann-Whitney U test, $p<0.001)$.

Table 2. The mass of carbon introduced into the surface layer in low-pressure carburising processes using acetylene.

\begin{tabular}{|c|c|c|c|c|}
\hline Process & Gas Type & $\begin{array}{c}\text { Pressure } \\
{[\mathrm{hPa}]}\end{array}$ & $\begin{array}{c}\text { Flow } \\
{\left[\mathrm{dm}^{3} / \mathrm{min}\right]}\end{array}$ & $\begin{array}{c}\text { Mass Increasing } \\
\text { Mean } \pm \text { SD [g] }\end{array}$ \\
\hline 1 & $\mathrm{C}_{2} \mathrm{H}_{2}$ & $1-3$ & 6 & $0.301 \pm 0.002$ \\
\hline 2 & $\mathrm{C}_{2} \mathrm{H}_{2}$ & $5-7$ & 6 & $0.318 \pm 0.004$ \\
\hline 3 & $\mathrm{C}_{2} \mathrm{H}_{2}$ & $5-7$ & 9 & $0.314 \pm 0.001$ \\
\hline 4 & $\mathrm{C}_{2} \mathrm{H}_{2}$ & $1-3$ & 9 & $0.320 \pm 0.001$ \\
\hline Total & - & - & - & $0.313 \pm 0.008$ \\
\hline \multicolumn{5}{|c|}{ Statistical analysis } \\
\hline \multicolumn{2}{|c|}{ Factor } & Range & $\mathrm{t}$ & $p$ \\
\hline \multirow{2}{*}{\multicolumn{2}{|c|}{ Pressure }} & $1-3 \mathrm{hPa}$ & -20.34 & $<0.001$ \\
\hline & & $5-7 \mathrm{hPa}$ & 2.56 & $<0.05$ \\
\hline
\end{tabular}

Table 3. The mass of carbon introduced into the surface layer in low-pressure carburisation processes using a carboniferous mixture $\left(\mathrm{C}_{2} \mathrm{H}_{2}: \mathrm{C}_{2} \mathrm{H}_{4}: \mathrm{H}_{2}\right.$ in a 2:2:1 ratio).

\begin{tabular}{|c|c|c|c|c|}
\hline Process & Gas Type & $\begin{array}{c}\text { Pressure } \\
{[\mathrm{hPa}]}\end{array}$ & $\begin{array}{c}\text { Flow } \\
{\left[\mathrm{dm}^{3} / \mathrm{min}\right]}\end{array}$ & $\begin{array}{c}\text { Mass Increasing } \\
\text { Mean } \pm \text { SD [g] }\end{array}$ \\
\hline 5 & $\mathrm{C}_{2} \mathrm{H}_{2}: \mathrm{C}_{2} \mathrm{H}_{4}: \mathrm{H}_{2}$ & $1-3$ & 7.5 & $0.278 \pm 0.008$ \\
\hline 6 & $\mathrm{C}_{2} \mathrm{H}_{2}: \mathrm{C}_{2} \mathrm{H}_{4}: \mathrm{H}_{2}$ & $5-7$ & 7.5 & $0.311 \pm 0.003$ \\
\hline 7 & $\mathrm{C}_{2} \mathrm{H}_{2}: \mathrm{C}_{2} \mathrm{H}_{4}: \mathrm{H}_{2}$ & $5-7$ & 11.25 & $0.306 \pm 0.004$ \\
\hline 8 & $\mathrm{C}_{2} \mathrm{H}_{2}: \mathrm{C}_{2} \mathrm{H}_{4}: \mathrm{H}_{2}$ & $1-3$ & 11.25 & $0.296 \pm 0.005$ \\
\hline Total & - & - & - & $0.298 \pm 0.015$ \\
\hline \multicolumn{5}{|c|}{ Statistical analysis } \\
\hline \multicolumn{2}{|c|}{ Factor } & Range & $\mathrm{t}$ & $p$ \\
\hline \multicolumn{2}{|c|}{ Pressure } & $\begin{array}{l}1-3 \mathrm{hPa} \\
5-7 \mathrm{hPa}\end{array}$ & $\begin{array}{c}-4.49 \\
2.34\end{array}$ & $\begin{array}{l}<0.01 \\
<0.05\end{array}$ \\
\hline
\end{tabular}


In processes where pure acetylene was used and in processes where a mixture of hydrocarbons was used for both pressure values tested, the effect of carboniferous gas flow rate was significant $(p<0.05)$ (Figures 1 and 2$)$. For the low-pressure range $(1-3 \mathrm{hPa})$, it was observed that the higher the flow rate, the mass of carbon in the carburised specimens increased. For the higher-pressure range (5-7 hPa), an opposite tendency was observed: the higher the flow rate (to $9 \mathrm{dm}^{3} / \mathrm{min}$ for acetylene and to $11.25 \mathrm{dm}^{3} / \mathrm{min}$ for the mixture, respectively), the slower the mass increase.
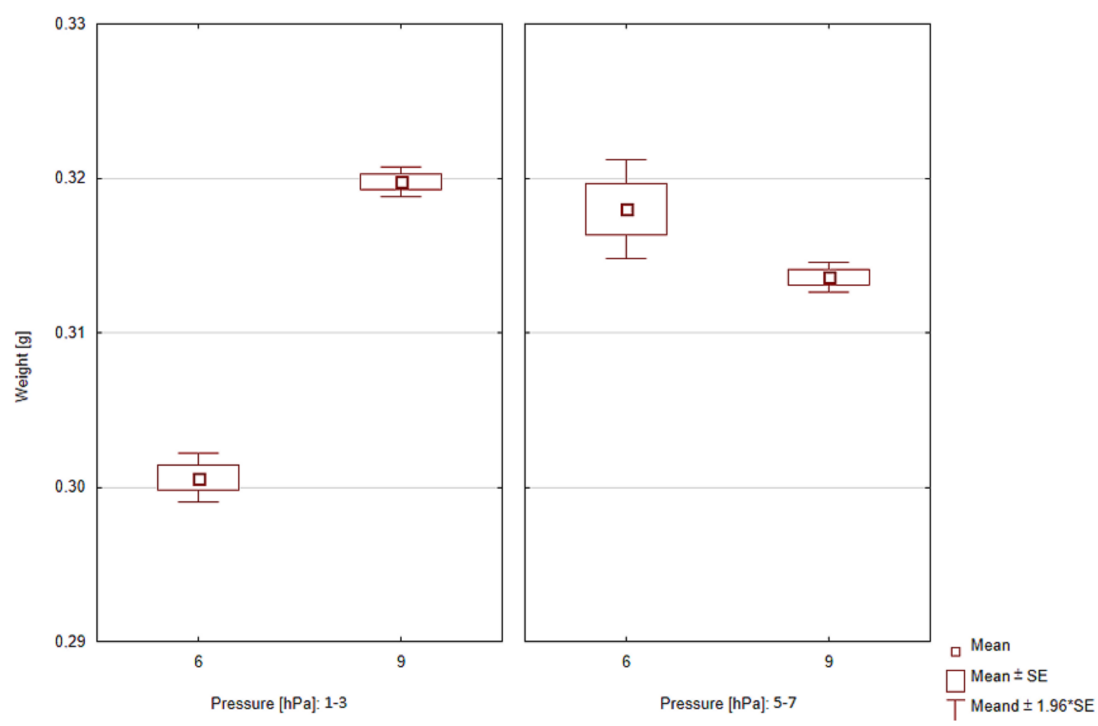

Figure 1. The effect of pressure and flow rate of the carburising mixture $\left(100 \% \mathrm{C}_{2} \mathrm{H}_{2}\right)$ on the increase in the mass of carbon in the low-pressure carburised surface layer.

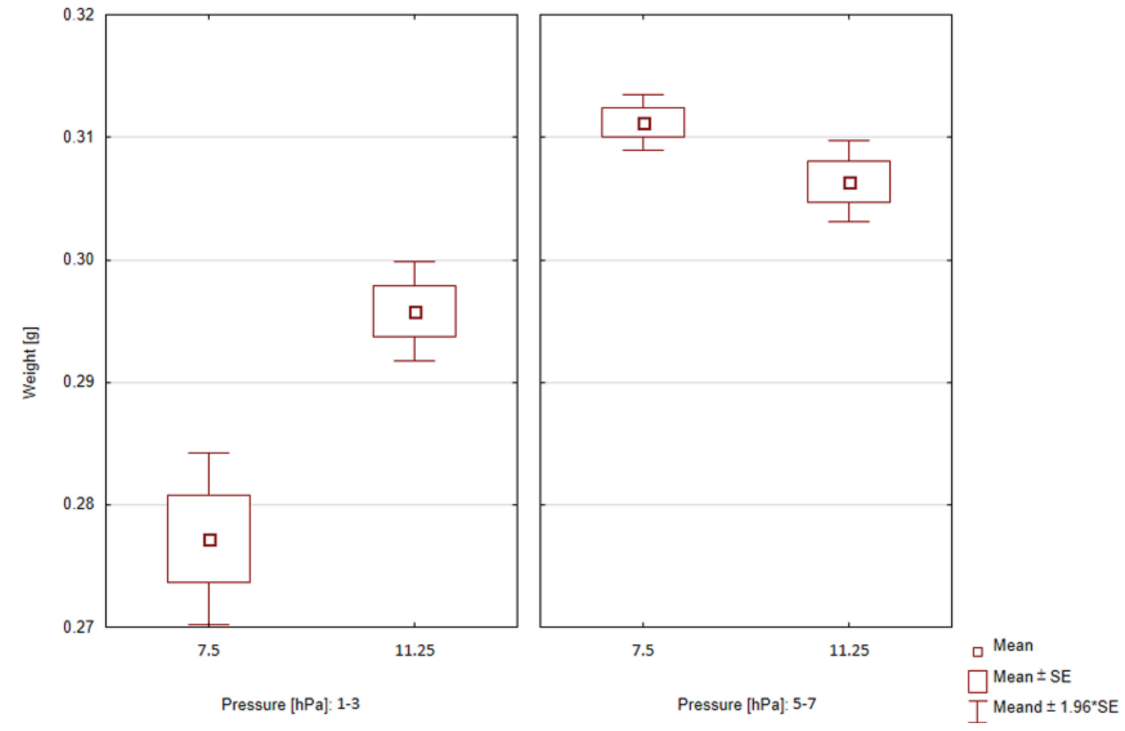

Figure 2. The effect of pressure and flow rate of the carburising mixture $\left(\mathrm{C}_{2} \mathrm{H}_{2}: \mathrm{C}_{2} \mathrm{H}_{4}: \mathrm{H}_{2}\right)$ on the increase in the mass of carbon in the low-pressure carburised surface layer.

\section{Discussion}

\subsection{Effect of Carboniferous Gas Type on Carburisation Intensity}

An analysis of the results of the experiment (Mann-Whitney U test) revealed that $100 \%$ acetylene is a more intensely carburising carboniferous gas than the Ac-Et-H mixture $(p<0.001)$. This is probably for two reasons. Firstly, it is the number of carbon atoms per mole of gas in pure acetylene and in the tested mixture; in acetylene, this number is $20 \%$ 
higher. The second factor is the sorption capacity of the carboniferous gases into metals. Gas of a high sorption strength is directly responsible for carburisation, while gas of lower sorption strength does not take part in carburisation until the amount of gas of a higher sorption strength is insufficient to cover the entire carburised surface [29]. Acetylene is a gas of higher sorption strength than ethylene, so carburisation with carbon atoms from its molecules occurs faster. Moreover, the bonding strength of carbon atoms in an acetylene molecule $(198 \mathrm{kcal} / \mathrm{mol})$ is higher than the bonding strength of ethane $(83 \mathrm{kcal} / \mathrm{mol})$ and ethene (ethylene) (145 kcal). This explains why, during carburising, acetylene better penetrates narrow blind holes in the carburised parts without disintegrating along the way and forms uniform layers. Regarding the soot-forming phenomena, Watanabe and Hirata [29] report that the decomposition reaction of a soot-forming hydrocarbon is expressed by the Equation (1):

$$
\mathrm{C}_{\mathrm{n}} \mathrm{H}_{\mathrm{m}} \rightarrow \mathrm{nC}_{(\text {soot })}+\frac{\mathrm{m}}{2} \mathrm{H}_{2}
$$

In the case of a gas of high bonding strength, the reaction does not proceed to the right, even if the $\mathrm{H}_{2} / \mathrm{C}_{\mathrm{n}} \mathrm{H}_{\mathrm{m}}$ partial pressure ratio is low. This explains why acetylene, at the correct pressure, allows carburising without the formation of soot.

However, carburising as intense as in pure acetylene is not always desirable; a mixture of acetylene, ethylene and hydrogen will result in less intense carburising, which is suitable for producing thin layers or carburising elements with small radius convex curves. Intense carburisation would result in carburising the whole cross-section of the element.

\subsection{Effect of Pressure and Flow Rate on Carburisation Intensity}

For a low range of process pressures (1-3 hPa), as the flow increased a significant increase in the mass of carbon in the carburised layer was observed in both mixtures. For the pressure range of $5-7 \mathrm{hPa}$, an opposite tendency was observed: an increase in flow rate resulted in a slower mass increase. This shows that a higher process pressure has a negative effect on the carburised layer formation. In acetylene carburising processes, 6.435 and $9.642 \mathrm{~g} / \mathrm{min}$ of carbon atoms were supplied to the chamber during the process (at flow rates of 6 and $9 \mathrm{dm}^{3} / \mathrm{min}$, respectively). In the case of mixture carburising, it was 6.314 and $9.471 \mathrm{~g} / \mathrm{min}$ of carbon atoms (at flow rates of 7.5 and $11.25 \mathrm{dm}^{3} / \mathrm{min}$ ). The calculated carbon quantities are independent of the pressure in the carburising chamber as the flow rate was measured upstream the chamber inlet at a pressure of $1013 \mathrm{hPa}$ and a temperature of $20^{\circ} \mathrm{C}$. Most likely, at a pressure of $5-7 \mathrm{hPa}$ and a higher flow rate, the conditions for carbon derivatives formation on the carburised surface occurred in the chamber. Mendiara et al. report that acetylene used in excess amounts tends to form soot while ethylene forms tar-generating compounds [13,21]. Kula and Pietrasik report that soot formation and partial polymerisation of atmosphere components to tar forms occurs not only on carburised surfaces as these compounds can also condense on cold parts of the furnace and in the pump system, causing their inefficiency and damage. However, the authors emphasise that this phenomenon is significantly less frequently observed than when propane is used $[30,31]$.

The research results presented in the "Results" section are compatible with the observations of Gorockiewicz and Łapinski, which reported that during LPC in pressure 5-7 hPa, an active carbon layer settles in the form of fine-crystalline graphite and hydrocarbon radicals on the surface of the parts (carbon deposit). The layer is appropriately thin when the supply of carbon from the atmosphere slightly exceeds the amount of carbon that can be absorbed by the surface. In this case, the carburizing process runs properly. In the case of a carbon supply largely exceeding the demand, the excess of carbon results in the precipitation of a considerable quantity of carbon deposit. In an extreme case, this occurs in the form of a tarry substance or soot, hampering the control of the carburizing process [32]. The formation of carbon derivatives at a pressure of 5-7 $\mathrm{hPa}$ would explain the deceleration of carbon transfer through the surface. At pressures of $1-3 \mathrm{hPa}$, these phenomena (i.e., soot- and tar-generating phenomena) would be reduced. For the pressure of $1-3 \mathrm{hPa}$ the 
carbon supply was apparently insufficient even at high flows; thus, the further increase in flow increased the mass of carbon gains in the carburised layers. The research shows that pressure is a more important parameter for the correct carburising process. Process purity depends on the proper pressure value. To sum up, for a fixed size of carburised surface, the flow rate should be an output value adapted to the type of mixture and pressure.

Based on the testing, all null hypotheses were rejected $(p<0.05)$. This means that carburizing in pure acetylene is significantly different from carburizing in acetylene mixtures, even on mixtures containing other carbon-bearing gases (ethylene, ethene). This results from the sorption capacity of carbon-bearing gases to metals and the bond strength of carbon atoms in acetylene molecules as described above. The pressure of the carbonbearing gases to carburising has an influence on the diffusion effectiveness. It is not a trivial relationship. Too much pressure may slow down sorption. The gas flow affects the efficiency of the process as well. In connection with that, it is possible to determine, experimentally, a range of pressures in which increasing gas flow increases the kinetic of the diffusion of carbon into the steel. Above this range, further increasing flow does not make a difference to the intensification of the process. Previous studies have failed to demonstrate that there is an interaction between pressure and flow of carbon-bearing gas. In the authors opinion, this does not mean that the interaction does not exist, but lack of proof results from the limitations of the conducted experiments.

The research described in the article does not apply to gas carburizing, which was not considered during the experiments. With regard to low pressure carburizing, it should be stated that only pressure and flow calculations performed with computer methods are useful for practical use. They give only an approximate result, but in terms of the calculation time and the possibility of their execution, they are the only method of credibly estimating the surface demand for carbon-bearing gas in low-pressure processes.

\section{Summary}

Within the limitations of this study, the following conclusions were drawn:

1. Carburising in pure acetylene is significantly different from carburising in acetylene mixtures, even on mixtures containing other carbon-bearing gases (ethylene, ethene) with carbon in the same amount.

2. It is possible to determine, experimentally, a range of pressures in which increasing gas flow increases the kinetics of the diffusion of carbon into the steel.

3. Only pressure and flow calculations performed with computer methods make it possible to credibly estimate the surface demand for carbon-bearing gas in lowpressure processes.

Author Contributions: Conceptualization, E.W.-K., M.K.; methodology, L.K.; investigation, M.K.; formal analysis, E.W.-K.; writing—original draft preparation, E.W.-K.; writing—review and editing, E.W.-K., M.K. and L.K.; supervision, M.K. All authors have read and agreed to the published version of the manuscript.

Funding: This research was funded by the Polish National Centre for Research and Development, Grant Number POIR.04.01.04-00-0087/15.

Institutional Review Board Statement: Not applicable.

Informed Consent Statement: Not applicable.

Data Availability Statement: Data is contained within the article.

Conflicts of Interest: The authors declare no conflict of interest.

\section{References}

1. Yada, K.; Watanabe, O. Reactive Flow simulation of vacuum carburizing by acetylene gas. Comput. Fluids 2013, 79, 65-76. [CrossRef]

2. Sawicki, J.; Kruszyński, B.; Wójcik, R. The Influence of grinding conditions on the distribution of residual stress in the surface layer of 17CrNi6-6 steel after carburizing. Adv. Sci. Technol. Res. J. 2017, 11, 17-22. 
3. Stachurski, W.; Zgórniak, P.; Sawicki, J.; Przybysz, M. Hardening-related deformations of gear wheels after vacuum carburizing and quenching in gas. Adv. Sci. Technol. Res. J. 2017, 11, 237-245. [CrossRef]

4. Kula, P.; Dybowski, K.; Lipa, S.; Pietrasik, R.; Atraszkiewicz, R.; Klimek, L.; Januszewicz, B.; Wolowiec, E. Investigating fatigue strength of vacuum carburized $17 \mathrm{CrNi6}-6$ steel using a resonance high frequency method. Solid State Phenom. 2015, $225,45-52$.

5. Kula, P.; Olejnik, J.; Heilman, P. Method for Under-Pressure Carburizing of Steel Workpieces. U.S. Patent No. 7,550,049, 23 June 2006.

6. Poor, R.P. Vacuum Carburizing with Unsaturated Aromatic Hydrocarbons. U.S. Patent No. 7,033,446, 25 April 2006.

7. Collin, R.; Gunnarson, S.; Thulin, D. A mathematical model for predicting carbon concentration profiles of gas-carburized steel. J. Iron Steel Inst. 1972, 210, 785-789.

8. Turpin, T.; Dulcy, J.; Gantois, M. Carbon diffusion and phase transformations during gas carburizing of high-alloyed stainless steels: Experimental study and theoretical modeling. Metall. Mater. Trans. A 2005, 36, 2751-2760. [CrossRef]

9. Antes, H.W. Calculating the gas flow rate for vacuum carburization. Heat Treating Progress 2005, 8, 51-53.

10. Herring, D.H. A case for acetylene based low pressure carburizing of gears. Thermal Proc. Gear Solut. 2012, 9, 40-45.

11. Bensabath, T.; Monnier, H.; Glaude, P.-A. Detailed kinetic modeling of the formation of toxic polycyclic aromatic hydrocarbons (PAHs) coming from pyrolysis in low-pressure gas carburizing conditions. J. Anal. Appl. Pyrolysis 2016, 122, 342-354. [CrossRef]

12. Khan, R.U.; Bajohr, S.; Buchholz, D.; Reimert, R.; Minh, H.D.; Norinaga, K.; Janardhanan, V.M.; Tischer, S.; Deutschmann, O Pyrolysis of propane under vacuum carburizing conditions: An experimental and modeling study. J. Anal. Appl. Pyrolysis 2008, 81, 148-156. [CrossRef]

13. Mendiara, T.; Domene, M.P.; Millera, A.; Bilbao, R.; Alzueta, M.U. An experimental study of the soot formed in the pyrolysis of acetylene. J. Anal. Appl. Pyrolysis 2005, 74, 486-493. [CrossRef]

14. Tsepov, S.N.; Krishtal, M.A. Characteristics of structure formation in the surface layers of metal during vacuum carburizing. Metal. Sci. Heat Treat. 1983, 25, 358-359.

15. Herring, D.H.; Peters, R.V. New-formula acetylene cool for heat treatment. Gear Technol. 2013, 9, 90-96.

16. Kubota, K. Vacuum Carburizing Method and Device, and Carburized Products; JH Corporation: Hanam-si, Korea, 1997.

17. Jordan, D. Versatile High Velocity Integral Vacuum Furnace. U.S. Patent No. 7,514,035, 7 April 2009.

18. Buchholz, D.; Khan, R.U.; Bajohr, S.; Reimert, R. Computational fluid dynamics modeling of acetylene pyrolysis for vacuum carburizing of steel. Ind. Eng. Chem. Res. 2010, 49, 1130-1137. [CrossRef]

19. Norinaga, K.; Deutschmann, O.; Saegusa, N.; Hayashi, J. Analysis of pyrolysis products from light hydrocarbons and kinetic modeling for growth of polycyclic aromatic hydrocarbons with detailed chemistry. J. Anal. Appl. Pyrolysis 2009, 86, 148-160. [CrossRef]

20. Saggese, C.; Sanchez, N.E.; Frassoldati, A.; Cuoci, A.; Faravelli, T.; Alzueta, M.U.; Ranzi, E. Kinetic modeling study of polycyclic aromatic hydrocarbons and soot formation in acetylene pyrolysis. Energy Fuels 2014, 28, 1489-1501. [CrossRef]

21. Sanchez, N.E.; Callejas, A.; Millera, A.; Bilbao, R.; Alzueta, M.U. Polycyclic aromatic hydrocarbon (PAH) and soot formation in the pyrolysis of acetylene and ethylene: Effect of the reaction temperature. Energy Fuels 2012, 26, 4823-4829. [CrossRef]

22. Slavinskaya, N.A.; Riedel, U.; Dworkin, S.B.; Thomson, M.J. Detailed numerical modeling of PAH formation and growth in non-premixed ethylene and ethane flames. Combust. Flame 2012, 159, 979-995. [CrossRef]

23. Tsuji, S.; Ishigami, I.; Yamanaka, K. Vacuum carburizing of low carbon steel with methane. Trans. Jpn. Inst. Metals 1987, 28, 48-56.

24. Xu, C.; Al Shoaibi, A.S.; Wang, C.; Carstensen, H.; Dean, A.M. Kinetic modeling of ethane pyrolysis at high conversion. J. Phys. Chem. A 2011, 115, 10470-10490. [CrossRef]

25. Harris, F. Case depth-an attempt at a practical definition. Metal. Progress 1943, 44, 265-272.

26. Wołowiec-Korecka, E.; Korecki, M.; Sut, M.; Brewka, A.; Kula, P. Calculation of the mixture flow in a low-pressure carburizing process. Metals 2019, 9, 439. [CrossRef]

27. Kula, P.; Olejnik, J.; Heilman, P. Hydrocarbon Gas Mixture for the under Pressure Carburizing of Steel. U.S. Patent No. 7,513,958, 7 April 2007.

28. Herring, D.H. Vacuum Heat Treatment. Principles | Practices | Applications; BNP Media II: Troy, MI, USA, 2012.

29. Watanabe, T.; Hirata, T. New Concept and Practical Operation of Carburizing and Nitriding; Agune Technology Center: Tokyo, Japan, 2015.

30. Kula, P.; Olejnik, J.; Kowalewski, J. Smart control system optimizes vacuum carburizing process. Ind. Heat. 2003, 9, 99-102.

31. Osterman, V.M. Development experience in low-torr range vacuum carburizing. Ind. Heat. 2005, 9, 95-99.

32. Gorockiewicz, R.; Łapinski, A. Structure of the carbon layer deposited on the steel surface after low pressure carburizing. Vacuum 2010, 85, 429-433. 